\title{
The OECD and Phases in the International Political Economy, 1961- 2011
}

\author{
Judith Clifton and Daniel Díaz-Fuentes \\ Faculty of Economic and Business Sciences, \\ University of Cantabria, Santander, Spain
}

\begin{abstract}
In 2011, the OECD turned fifty. To provide a broad foundation for further thinking on this organization, we analyse its evolution over half a century from two perspectives: phases in the international political economy and the literature on IPE. By so doing, we uncover two paradoxes. Firstly, we find that the organization's evolution closely mirrored major phases in the post-war international political economy until recently. However, the OECD's long-term dependence on the West has now become an obstacle to its efforts to adapt to the latest phase, characterised by the rise of non-Western powers. Secondly, we show that, during the OECD's "golden age”, scholars paid relatively little attention to the organization but, from the 2000s, as the organization faced an unprecedented challenge of its potential economic decline, IPE literature on the organization blossomed.
\end{abstract}

\section{KEYWORDS}

OECD; global economic governance; international political economy; IPE.

\section{INTRODUCTION}

Fifty years ago, in September 1961, the Convention establishing the Organization for Economic Cooperation and Development (OECD) came into force, effectively establishing a framework upon which would be built a long-lasting relationship between the world's major economies of that time, an alliance dominated by the transatlantic nexus between the US and Western Europe. As an organization, the OECD was far from a "tabula rasa", inheriting, as it did, the assets of its predecessor, the Organization for European Economic Cooperation (OEEC), including its professional and administrative staff, its Parisian headquarters and infrastructure, and its members, whilst adding the US, Canada and Spain. The Americans had promoted the setting up of the OEEC in 1948, in the shadows of the unfolding Cold War, with the prime task of executing Marshall Aid distribution towards the recovery of certain Western European countries (OECD, 2011a: 47). Half a century on, the OECD represents one of the world's pre-eminent forums where officials from member and non-member countries meet to deliberate on a wide range of economic, social, technical, environmental and political issues. Though the OECD cannot provide funds, condition finance, enact laws or enforce regulation, policymakers and scholars alike have acclaimed its pioneering and successful implementation of "soft governance" tools, such as peer pressure and review (Pagani, 2002), and for its epistemic influences on policy-makers (Carroll and Kellow, 2011). The OECD's fiftieth anniversary was our major motivation for embarking on a project to subject the organization to greater scholarly analysis, though we think there are three other, related - 
and more important - reasons for why the study of the OECD has become pressing, if not, urgent, today.

Following Kaul et al. (2003), one of the consequences of globalization is that public goods (and bads) require management on an increasingly global scale. In the context of the ongoing financial and economic crisis, the OECD could make key contributions towards their solution, such as producing new policies to redesign an efficient, reliable, sustainable and fairer regulatory financial framework, as well as proposing socio-economic policies to ease the effects of the crisis. At the highest level, the OECD could serve the global webs of governance well, by offering critical support in terms of the delivery of data, analysis and policy on a wide range of issues, particularly to the informal international organizations which lack secretariats, most importantly, the G20. Indeed, the OECD’s current Secretary General, Ángel Gurría, cites these roles among his core strategic ambitions for the future of the organization (Gurría, 2011).

And yet the OECD faces an unprecedented organizational crisis which threatens to undermine its future legitimacy as a credible player in international economic governance. While this is not the first time the OECD has had to reform, we argue this crisis is the most daunting challenge the organization has had to face to date. Unless the OECD changes course - particularly in regard to relaxing the logic of its historically "exclusive club" membership - it will be unable to halt the gradual erosion of its economic and political legitimacy, as its members weight in world GDP, trade and population moves into steady decline, as we will discuss in Section 1. Following Mahbubani (2011:133), power and legitimacy are inevitably and tightly linked. Clearly, the OECD cannot claim it is the legitimate economic policy advisor to the world when non-members use non-OECD formulas to attain superior growth! But it is not just the decline of OECD members as a percentage of the world economy that is the issue. The OECD staff has historically focused and become expert on producing policies designed by and for its members, predominantly advanced Western capitalist economies, using a limited range of Anglo-Saxon inspired neoliberal solutions, particularly from the 1980s. Mahbubani (2008: 69) labelled it a "sunset organization", berating it for having nothing to offer to the emerging powers or to the developing world. As other economies muscle in to take their share of world growth and trade, it is far from clear whether OECD staff has the analytical heuristics, knowledge, linguistic and cultural capabilities, contacts and experience to offer relevant policy advice to, and help coordinate, these differently structured and diverse economies. The OECD's highest body, the Council, has formally recognised organizational crisis, and has officially stated that the organization must fundamentally broaden its engagement with key economic actors or face future impotence in the task of governing the world economy (OECD, 2006). In response, the OECD has undertaken unprecedented organizational reform, driven by the stated aim of making the organization much more "inclusive", evidenced not just through membership expansion but also outreach activities across Asia, Latin America and Africa (OECD, 2009). The future of the OECD and its place in the system of global economic governance hinges on its successful transformation into an organization which increases its relevance for a larger slice of countries making up the world economy and population. But it is not straightforward to transform what was for decades a closed club of Western capitalist economies into a more inclusive and heterogeneous organization. In practice, its historic dependence on the West is proving sticky, impeding reform, whilst limiting the organization's capacity to respond to the needs of the rest of the world (Clifton and Díaz-Fuentes, 2011).

These forward-looking questions help contextualize contemporary analysis of the OECD as it reaches its fiftieth anniversary. To look forward, it is often helpful to look 
backward. However, when we do turn back to the historical literature on the OECD, we find a fourth major reason to justify focusing our attention on this organization. Until the 1990s, scholars paid quite scant attention to the organization in comparison with many of its peers. Moreover, of the literature published on the OECD between the 1960s and the 1980s, most is either prescriptive or rationalist in approach. Whilst the former focused on what the OECD should do or be in order to best serve the interests of nation states (particularly those of the US), the latter tended to treat the OECD as an "empty shell" where the US met its allies and exercised its power. Much was left unknown about the OECD itself, for instance, how it collected and analysed information and data, how it produced policy concepts and principles, and whether these products or services made any difference in national or international settings.

We argue that the OECD does matter to scholars of international political economy, and that neglecting this organization can skew our understanding of global economic governance. A better understanding of the OECD and its role is important because policy-makers may comply with regulation not only when it is mandatory to do so, but also if they perceive that the proposed regulation or policy is legitimate. For example, practices pioneered by the OECD, such as peer pressure and review, or policy concepts such as "best practice", "principles" and "international standards", influence policymakers when they perceive that these practices or concepts will help tackle the problem or issue they seek to resolve back home. The OECD calls this its "disciplinary powers" (OECD, 2011a: 29). But ideas, concepts and policies do not come from a vacuum, and it is also important to analyse how the OECD produces and diffuses them, as well as what impact they have.

Combined, these four major points make the study of the OECD timely and important. In this context, our aim is to shed some new light on the OECD from a specifically international political economy perspective. Wolfe (2008) and Woodward (2009) recently published descriptive historical overviews of the organization. Here, we take a different approach by analysing the OECD's evolution within the double context of the international political economy and IPE literature. We derive the framework of the international political economy from the seminal contributions of the economist Angus Maddison who, as well as being a pre-eminent scholar on the evolution of the world economy, helped pioneer much of the national account data collection as an official in the OEEC and subsequently OECD Department of Economics and Statistics. In the first section, we use official data, information from interviews with officials, and other primary and secondary sources, to show how the OECD's evolution closely mirrored major phases in the international political economy, until the most recent phase. We also show that, from its origins to the present time, the OECD remained very much a club of the Western, capitalist countries. We then point out how this led to the paradox that the OECD's dependence on the West, appropriate perhaps for the first two phases of the post-war international political economy, has hampered its ongoing reform, designed to move the organization into the current phase of international political economy, a phase where the West is being increasingly challenged by growth from the East and the South. In the second section, we present a highly synthetic overview of the OECD from the perspective of some of the major IPE contributions on the organization. We contextualize the three papers included in this special section therein. We highlight the paradox that scholars paid very little attention to the OECD during its "golden" days, whilst scholarship blossomed from the 2000s, as the OECD entered the most serious of its organizational challenges to date.

\section{THE OECD IN THE INTERNATIONAL POLITICAL ECONOMY}


In this section, we argue that the OECD's evolution over half a century followed a path which very closely mirrored major phases in the international political economy, until the most recent phase, as identified by Maddison. We then argue that the OECD's ongoing reform, which its officials designed to adapt to this latest phase, is being seriously hindered by its long-term path-dependency on the West. Elsewhere, we have made these points using information based on its membership, the size and composition of its bureaucracy, major budgetary changes, and the kinds of services it provided (Clifton and Díaz-Fuentes, 2011). Here, we focus just on two of these issues: the logic of membership and the composition and size of its bureaucracy. We briefly sketch out the phases in the international political economy before turning to OECD membership and bureaucracy.

\section{Phases in the international political economy}

Writing at the beginning of the 1990s, Maddison (1991) argued the post-war period could be divided into two major phases. He labelled the first phase, from the post-war to 1973, the "golden age", as, in the aftermath of war and the Great Depression, the GDP of the OECD countries grew at nearly 5 percent, its exports grew nearly 9 percent and unemployment was low at 2.6 percent. He called the next phase, from 1973 to 1989 “cautious objectives”. In this period, OECD GDP growth fell to 2.6 percent, export growth reached only 3.8 percent and unemployment increased to 5.6 percent. Even during this early period, non OECD countries were growing at a faster rate than OECD ones, but due to faster demographic growth outside the OECD, the OECD was still getting richer when measured by GDP per capita (see Table 1).

\section{TABLE 1}

During the 2000s, Maddison identified a third phase in the post-war international political economy, which he referred to as "shifting wealth", which is more generally associated with the phase of "globalization". The three post-war phases have been recently described in a Maddison-OECD joint publication, Perspectives on Global Development: Shifting Wealth (OECD, 2010a). In the latest phase, stretching from 1990 to the present, OECD GDP growth continued to decelerate to 2.3 percent, while nonOECD GDP grew by over double, at a record 4.9 percent. OECD exports grew by 4.7 percent, while in the non-OECD they grew at 9.3 percent. Maddison (2007) forecasted that by 2030, non-OECD countries will account for nearly 57 percent of world GDP (OECD, 2010a). Andrew Mold, Head of the Finance Development Unit at the OECD, argued that Maddison underestimated the importance of non-OECD growth, which he calculated will reach nearly 70 percent of world GDP by 2030 (GDP (Mold, 2010).

\section{OECD membership logic 1961-2011}

In 1961, the OECD replaced its predecessor, the OEEC. The US had promoted the establishment of the OECD in 1948 for the primary purpose of managing Marshall Aid to certain Western European countries but, by 1952, the US cut Marshall Aid. Rather than closing the OEEC down, a special committee decided it would be charged with issues relating to the European economy. Contemporary scholar Gordon (1958) labelled it the "economic NATO", and considered it an instrument of the Cold War. Once Europe recovered at the end of the 1950s, there were more discussions about closing it down. However, the US, France, Western Germany and the UK agreed that there were 
advantages to establishing an institution based around the transatlantic alliance. Most importantly, they could use this institution to better co-ordinate inter-dependent issues relating to trade, finance, development and other economic areas (Aubrey, 1967).

According to its Convention, the OECD's role was to promote policies to achieve high, sustainable economic growth and employment, world trade and economic development (OECD, 1960).

When the Convention came into force in September 1961, the OECD inherited all existing members of its predecessor: Austria, Belgium, Denmark, France, Greece, Iceland, Ireland, Italy, Luxembourg, the Netherlands, Norway, Portugal, Sweden, Switzerland, Turkey, the United Kingdom and both occupied zones of Western Germany. The OECD added to these members the US, Canada and Spain, thus consolidating the transatlantic alliance. Beyond the original twenty members, however, the OECD took a purposefully restrictive attitude to further member expansion, so the "club" remained "exclusive". In this phase, the OECD only extended membership to Japan (1964), Finland (1969), Australia (1971) and New Zealand (1973). After the United States' hegemonic role received a fatal blow in 1973, with the collapse of the Gold Standard and the first oil crisis, the OECD underwent a freeze on membership expansion and its budget, whilst recruitment stagnated.

It was not until after the end of the Cold War, from the beginning of the 1990s, when OECD members and officials readdressed the question of further membership expansion. With a new world order coming into play, old political divisions no longer made sense. Members agreed on expansion, though they implemented this with great caution. Despite the fact that many countries in Eastern Europe expressed an interest in joining, OECD officials managed accession according to their so-called "symmetrical" membership logic. ${ }^{1}$ Fundamentally, officials wanted to balance European and nonEuropean newcomers, so as to dilute its European-ness. OECD members finally agreed to accept just three (four, after Czechoslovakia divided) Eastern European candidates and, to balance this, two non-European countries. Hence, Mexico (1994), the Czech Republic and Poland (1995), Hungary and South Korea (1996) and, finally, the Slovak Republic (2000) joined.

For decades, OECD officials and members had not generally considered expansion as part of their strategy priorities. This opinion changed sharply from the 2000s in the context of the rise of the emerging economies and the OECD's recognition that the economic weight of its own members was in decline. Official strategic policy began to promote and a more "inclusive" attitude towards non-members and to seeking out increased contact above all with important emerging markets (OECD, 2009). The OECD implemented a so-called “enhanced engagement” programme to ramp up participation by Brazil, China, India, Indonesia and South Africa from the mid 2000s in the hope they would later become its members. Despite these efforts, only four new members joined: two from Europe, Estonia and Slovenia, and two non-Europeans, Chile and Israel, all during 2010. Though the OECD and the Russian government had signed Russia's roadmap for accession in 2007, progress was slow.

So, until the 1990s, the logic of OECD membership policy followed an "exclusive club" approach, based on the transatlantic nexus "plus Japan". The "club of the rich" enjoyed a membership that represented the dominant share of the world economy. It was not until OECD members' shares of the economy started to slip, inexorably, from the 2000s, that officials used membership policy as part of the organization's strategy to woo important emerging countries, particularly, China. Despite these efforts, the incoming members have not helped the organization avoid its own decline. In 1989, with 24 members, the OECD enjoyed over 56 percent of world GDP and 70 percent of exports. 
By 2010, with 34 members, it only boasted 50 percent of world GDP and 60 percent of exports. The OECD predicts its share of world GDP will shrink to 43 percent by 2030 and to 41 percent of exports (Table 1). And it remains unclear whether this "Western club" has much to offer countries with differently structured economies. The OECD needs the emerging markets, but do they need the OECD?

\section{OECD bureaucracy 1961-2011}

We argue that one of the primary reasons emerging markets may hesitate when it comes to deepening collaboration with the OECD is the organization's long-term dependence on the West. We can see this Western dependence in many different attributes of the organization: here, we show it through an analysis of the staff employed by the OECD.

The OECD's bureaucracy, the Secretariat, is virtually entirely located at its Parisian headquarters, with tiny branches in Berlin, Mexico City, Tokyo and Washington. OECD staff work either in the General Secretariat, in one of the departments, of which there are currently twelve, ${ }^{2}$ in a special body, of which there are ten, ${ }^{3}$ or in one of the Committees, sub-committees or working groups. ${ }^{4}$ Whilst traditionally, many staff enjoyed open-ended contracts, the percentage of fixed-term contracts increased from the 1980s. As Marris (1983) observed, this changed somewhat the profile of OECD officials, making many of them more representative of ongoing national politics in their country of origin rather than of the OECD as an IO per se. Arguably, then, staff nationality became even more important than previously. The OECD categorises its staff into four major groups: professional staff, including economists and policy analysts; secretarial or technical staff; manual staff; and translators.

Who did the OECD employ at its Secretariat over fifty years? In 1961, when the OECD inherited 617 officials from the OEEC, over 70 percent of whom were French nationals, followed by the British, in second place, with 13 percent. During the period 1961-1973, its bureaucracy grew and the number of officials increased to $1,580 .^{5}$ Still, in 1973, French, British and to a lesser extent, US, officials dominated, making up nearly three-quarters of the total. Though there was some growth in the second half of the 1970s, by the 1980s, stagnancy followed and staff scarcely grew. After the Cold War ended, recruitment grew again, gradually, reaching 2346 officials by 2010. But, even in 2010, French, British and US nationals still constituted over 58 percent of all officials, including 45 percent of the professional posts. In contrast, Japan, a member from 1964 and second contributor to the core budget after the United States, remained sorely underrepresented for decades, and still only boasted 65 officials in 2010.

Clearly, the size and composition by nationality of staff provides only a partial and very imperfect picture about an organization. But the historic domination of the OECD by the three post-war allies is striking. During periods of recruitment expansion, the influence of the French and British waned, as other nations, including the US, became better represented. But, even in 2010, these three countries remain very heavily represented whilst other important economies are seriously under-represented. Whilst the US was the leading contributor to the core OECD budget in 2010 at around 22 percent, France and the UK contribute just over 6 percent each (OECD, 2010b). We argue that this long-term dependence on the West, as illustrated by both membership and staff, is part of a broader path-dependency that the OECD has yet been unable to shake off. This dependency serves to restrict the organization's linguistic, cultural, scientific and diplomatic capabilities, and is now proving a handicap in its ongoing reform towards attracting broader participation on the road towards its becoming a more inclusive, global 
organization. It is a paradox that the OECD is attempting to force itself to move with the times, into the next phase of shifting wealth, but is itself restricted to do so because of the weight of its past. This inheritance also makes the OECD unattractive. For an on-looking Asian economy potentially interested in OECD activity, such as China or India, Japan's relative lack of success in engaging in the organization, plus a continued dominance by the three post-war allies, does not look encouraging (West, 2011).

\section{THE OECD IN IPE}

In this section, we shift our analysis to consider the OECD's evolution as seen from the IPE literature over fifty years. Scholars have repeatedly pointed out that the OECD has received inadequate attention in the literature on IOs in comparison with its peers, such as the IMF, the World Bank, the WTO, the European Union, or NATO (Woodward, 2009). We suggest there are two main reasons for this. Firstly, from its origins as the OEEC, a culture of "secrecy" shrouded the organization because many discussions, such as those on Marshall Aid distribution, were held behind "closed-doors". Observers claimed this facilitated negotiations on highly sensitive questions (Lintott, 1949). This tradition continued, even when the OECD replaced the OEEC, and scholars trying to study the organization repeatedly complained about problems of access to information and obstacles caused by over-rigorous classification of documents (Aubrey 1967: 130; Camps 1975: 47, Blair, 1993, xii). From the 1990s, the OECD adopted a more open policy to outside observers, which included a swifter and more comprehensive declassification policy. Secondly, as pointed out by Barnett and Finnemore (1999), rationalist accounts of IOs, which dominated until the 1990s, focused primarily on the materialist use states made of them. Since the OECD offered little in the way of financing or mandating states, rationalist accounts underestimated the significance of its subtler forms of activities, including norm-making, influence and persuasion. Other approaches which became more common from the 1990s, focusing on institutions, bureaucracies, ideas, discourses and norms, such as constructivism, had more relevant theoretical tools which were better suited to analyse the OECD's activities.

Despite this lack of attention to the OECD, in this section, we synthetically and selectively analyse the evolution of the OECD as seen from some of the major contributions of political economy and IPE over half a century. We use the three phases already identified, spanning from 1961-1973, 1973 to 1989, and the 1990s to the present, as an organizing and analytical device.

The "golden age": 1961-1973

The "golden age" for OECD countries was also a "golden” period for the organization. The OECD's original twenty, increasing to twenty-four, member countries accounted for the lion's share of booming world economic growth. In 1961, members comprised 53 percent of world GDP and 55 percent of world exports, which increased to 59 percent and 72 percent by 1973, respectively. ${ }^{6}$ As we have seen, staff numbers more than doubled in this period and, with them, the OECD's budget, the bulk of which pays for personnel. Paradoxically, however, scholars paid relatively little attention to the organization. One important source of scholarship was the journal International Organization, which published short, highly descriptive pieces on the OECD's activities, as well as a dozen analytical journal articles. US or US-based authors dominated authorship on the OECD in this period. By far their most common angle motivating research was that of evaluating the prospects for US foreign economic policy. In this 
literature, these authors dealt with the OECD as one of many international organizations where US interests could be protected and advanced.

The Council of Foreign Relations (CFR) commissioned the most important monograph on the OECD during this phase and, indeed, the next phase. On this occasion, they commissioned the study to Henry Aubrey, a political economist and war immigrant from Austria, formerly at the New York Federal Reserve Bank (Heilbroner, 1970). ${ }^{7}$ At the heart of this, largely prescriptive, monograph, was a search for the justification for establishing the OECD from the US perspective. The general argument was that, under the settlement between the US and Europe as established by the OEEC, the US had prioritised security over economic requirements, because they viewed the communist threat as their top priority. However, as Europe recovered, the US became increasingly irritated with European trade discrimination. Other scholars, including Diebold (1963: 673) and Gilpin (1971: 409), also deemed the former security/economics "trade-off” unsustainable. The US now wanted to ensure Europe would collaborate as a partner with the US on a new, more equal, footing, sharing in the costs of the increasing interdependence of trade, finance, development and other issues. These scholars viewed the OECD as one way important way of institutionalizing this transatlantic cooperation. Scholars viewed the OECD as a "black box" and assumed it was an instrument of nation states, particularly, the US. Aubrey (1967) considered that all institutional changes to the design of the OEEC for the new OECD could be explained by US interests. He argued that, for instance, the decisions to retain the Code for Liberalization of Capital and Invisibles, whilst eliminating the Code for Liberalization of Trade, was due to US foreign policy objectives.

\section{“Cautious objectives”: 1974-1989}

American hegemonic decline in the early 1970s marked a transition into a difficult period for the OECD, particularly during the 1980s. The international monetary system based on the dollar collapsed. A system of floating rates, increased capital mobility and inwardlooking domestic policy concerns with monetary and price stability ensued (Maddison, 1991). For the entire period, the OECD froze membership expansion, recruitment came to a virtual standstill and, as a more hostile attitude towards IOs grew in parallel with the coming to power of right-wing administrations in the US, the UK and beyond, its budget stagnated. At first, literature on the OECD bore similarities to that published in the first half of the decade. However, increasingly, scholars began to publish work which directly, vehemently, attacked the organization, during the 1980s.

One of the most important works on the OECD in the second half of the 1970s is Camps (1975). The CFR commissioned Miriam Camps, formerly a State Department Official turned foreign affairs researcher, to write the second monograph on the OECD (The New York Times, 2 January, 1995). Like Aubrey (1967), they commissioned her to analyse the OECD from the perspective of how best it could serve US foreign policy interests. The main function of the OECD, from this angle, was as a kind of "antechamber" which could be used by the US and its allies to convene, agree upon, and shape strategic policy initiatives on issues of interest, including trade, investment and economic development. Because the OECD only included a small number of like-minded countries, members could arrive swiftly at a decision. Once the allies had come to a joint decision or posture, they could then present this to the United Nations and its specialised and associated agencies such as the IMF, World Bank, ILO and WTO. Following a similar logic, Meltzer (1976) analysed how, during the 1960s, the US used a flexible, "wise men" format, at the OECD to advance their trade interests. When the G77 
countries called for trade preferences as part of the wider "New International Economic Order" during the 1960s, US trade officials used the OECD to meet with their West European peers to agree on a common response. Once the US officials agreed on a position, they brought this home for approval in the US as well as used the position in discussions at the United Nations Conference on Trade and Development.

Increasingly, scholarly focus on the OECD diverged from being only concerned with US foreign policy and took on broader perspectives, including studies which analysed the organization per se. At the same time, scholars started to attack, indirectly or directly, the OECD. Two scholars in particular, Michele Fratianni and John Pattison, became well-known to the perhaps sensitive OECD officials as among its strongest critics (Marris, 1983). Fratianni and Pattison (1976) criticised the OECD's analysis of the causes of the 1973 financial crisis. They argued that, in its refusal to assign blame to any particular government or central bank, it was acting as a political animal by opting to survive whilst producing bland and toothless reports. In a later article, Fratianni and Pattison (1982) loosely applied collective action theory to argue that the US should partially disengage from its former commitments to international organizations, particularly due to loss of economic power since 1973. They argued that this disengagement would help reduce inefficiencies and avoid free-riding. Using club theory, they concluded that smaller clubs of countries were more productive and efficient, thus, they argued the United Nations was the least efficient of organizations, the informal G-5 (the US, the UK, West Germany, France and Japan) the most efficient, whilst the OECD lay somewhere in the middle.

In a critical analysis of the so-called McCracken Report (OECD, 1977), Robert Keohane (1978) also berated the OECD from a different perspective. He argued that the organization had shifted its position from a Keynesian to a neoliberal posture in the interests of serving only the most powerful of its members. If Keohane was right, at least about the intentions of the OECD, these efforts did not go far enough. During the 1980s, the OECD fell out of favour with Ronald Reagan and Margaret Thatcher, who found its work insufficiently market-oriented. As the summitry evolved, the G-7 meetings became an increasingly important, annual event where the most powerful states in the world discussed cooperation on economic policy and other issues. The OECD initially appeared as the ideal actor to provide Secretariat functions, which of course the G-7 lacked.

However, Putnam and Bayne (1984: 142-4) describe how, although the OECD was at first brought in to help with summit preparation, conducting commissioned analysis and producing reports, this close relationship quickly became tense. The expectation at the G7 summits was for the OECD to clearly endorse policies that would not necessarily be accepted by all its members, whilst participating in work that only benefited some of them. With hindsight, Stephen Marris, Economic Advisor to the Secretary General during the 1980s, was right when he argued that the chaos of the McCracken Report (1977) was due the fact that there had been an attempt to fast-track neoliberal economic ideology into the Department of Economics, but that this had failed, at least in the shortterm, because of the training in Keynesian economics which most of its economists had received. A paradigm change was possible, but would take time (Marris 1983).

\section{Globalization and Shifting Wealth: 1990-2011}

In the final phase of international political economy, the OECD faced two, major, crises: the first was political, the second, economic. Firstly, from the 1990s, members questioned the continued political rationale of the OECD in the light of the end of Cold War tensions. Donald Johnston (2011: 104), Secretary General from 1996-2006 
described the atmosphere as "turbulent, even traumatic", due to the severe budget cuts and repeated job uncertainty for staff. Secondly, from the 2000s, the relative economic weight of OECD members declined. This shift in the world economy undermined the OECD's former claim to represent a club of "rich, successful” nations. Paradoxically, research on the organization blossomed during this period. This increased scholarly attention on the organization was likely influenced by the consolidation of other perspectives on international organizations beyond rationalism (Blyth, 2009), offering new tools for their exploration (Barnett and Finnemore, 1999). Additionally, non-US scholarship thrived, in particular, from Canada and Europe.

During the 1990s, the theoretical tools deployed to analyse the OECD remained largely in the rationalist tradition. Blair (1993) represented one of the first, noncommissioned, monographs on the OECD, and used realist theory to analyse the success of intergovernmental trade negotiations inside the organization (on completion, interestingly, the OECD hired him!). Former Head of the OECD Economics Department, David Henderson (1993) also adopted a rationalist perspective to explain how the outcome of business executed within the OECD was very much a product of the interests of its "client-countries".

The recent period, from 2000 onwards, represented the richest, most diverse and productive period for research on the OECD so far. Woodward (2009) and Caroll and Kellow (2011) published academic (non-commissioned) studies on the organization, whilst Mahon and McBride (2009) and Martens and Jakobi (2010) published edited volumes which focused on the mechanisms of OECD governance. Much of the new research enquired as to the nature and importance of the OECD per se in world politics, rather than merely considering the organization as one arm of a country's foreign policy, or as an arena of intergovernmental politics. Amongst this new research, important fields of study examined the importance of ideas and discourses, and the role they played in influencing policy. Marcussen argued that the OECD could be understood as a powerful disseminator of Anglo-Saxon and, particularly, neoliberal ideas, such as privatization and monetarism. Moreover, he argued that, in the post Cold War period under pressure from the Americans for demonstrating value for money, the organization had become their “ideational agent” (2004:101). Mahon (2006) introduced more nuances, and explained how and why organizations produced and later diffused multiple, partially overlapping, sets of discourses. In her paper on the OECD Jobs Strategy in this issue, Mahon (2011) stressed that it was not accurate to simply consider the OECD as a monolithic engine of neoliberalism, and illustrated this by tracking the flow of ideas and discourses on jobs by the Department of Economics and the more socially sensitive Directorate for Employment, Labour and Social Affairs. Whilst the former promoted a neoliberal approach promoting work and wage flexibility, the latter supported "flexicurity", referring to a system which sought a balance between economic competitiveness and social protection. Sharman (2009) analysed what happened to ideas and policies once they left the OECD by showing how "speech" in the form of the OECD's blacklisting of tax havens could be effective in changing governments' behaviour, even when this was not necessarily in their self-interest.

Other research rectified previous treatment of the OECD as a black box by analysing its inner structures, including the roles of governments, agencies, transnational and national organisms, bureaucracy and individuals therein. In their comparative study of IOs, Trondal, Marcussen, Larsson and Veggeland (2010) made more visible the role of bureaucrats by enquiring when, why and how they supplemented intergovernmental decision-making, and the characteristics of the so-called "compound dynamics" which shaped their actions. In this issue, Marcussen and Trondal (2011) adopted this approach 
with a specific focus on the OECD. In the paper by Howarth and Sadeh (2011), also included in this issue, the authors sought to explain how the OECD's Committee on Capital Movements and Invisible Transactions (CMIT) became so entrepreneurial in its activities to liberalize capital flows, even when this many members did not support this policy. They found answers in the unique institutional organization of the CMIT itself, which enjoyed wide discretion, weak monitoring and a lack of institutional checks and balances to control it.

Finally, another new stream of research has emerged on IOs and public goods. Traditionally, scholars analysed the concept of public goods and externalities at the national level, but Inge Kaul and her colleagues argued that globalization has meant public goods have taken on an increasingly global or regional dimension (Kaul et al., 1999; 2003; 2006). These authors argue that IOs have behaved for too long as clubs in the interests of a few, rich countries. They argue IOs must reform urgently by aligning who they represent (broader inclusion and representation) with what they produce (global and regional public goods). These authors direct most of their attention to the United Nations, whilst they virtually ignore the OECD. Clifton and Díaz-Fuentes (2011) applied this argument to the case of the OECD, and revisited and reversed Fratianni and Pattison's (1982) proposition that favoured small clubs. They argued that a more inclusive, open and representative OECD will lend the former Western club a new legitimacy, and make it better positioned to help providing much-needed global public goods.

\section{CONCLUSIONS}

The OECD's commemoration of fifty years since ratification of its Convention in 1961 was our formal motivation to embark on a project to subject the organization to more analytical scrutiny. We argued here that there are at least three additional, and more important, reasons, which justify its study: the importance of international organizations in providing global public goods; ongoing organizational reform in the face of shifting wealth to the East and South; and the long-term lack of scholarship on the OECD. We then analysed two important aspects of the evolution of the organization: its membership logic and the size and composition of its staff. We showed how, in both cases, the

OECD's evolution mirrored closely developments in the post-war phases of international political economy, until recently. The paradox we noted here was that the OECD's historic over-reliance on the West has rendered it unattractive to the potential new members it is now seeking to attract. We illustrated this with data on staff composition, which remains heavily skewed towards the three post-war allies, France, the US and the UK, but we have made a similar argument using other features of the OECD, such as its narrow, Anglo-Saxon-inspired approach to economic policy-making from the 1980s (Clifton and Díaz-Fuentes, 2011). We then synthetically and selectively examined the IPE literature on the OECD and organised them into the three phases of the international political economy. We showed the paradox that scholars paid very little attention to the organization during its "golden" years, and that scholarship started to bloom on the OECD from the 2000s, as the organization entered its most serious organizational crisis to date.

It is not an option for the OECD to continue to witness the decline of its members in the world economy and accept its growing impotence. This decade, the OECD must break decades of Western dependence and put into practice deep and difficult deep internal reform to emerge as a much more inclusive, diverse and open Organization for Economic Cooperation and Development. It cannot help govern the world economy if it 
only represents an increasingly dwindling share. It is the task of scholars to watch, wait and evaluate this transformation.

\section{ACKNOWLEDGEMENTS}

The authors would like to thank many people at the OECD especially Andrea Goldstein, Eric Burgeat, Jean-Claude Paye, Nicolas Bray and Josef Konvitz. Additional thanks go to the University of Cantabria for financing field-work, LSE librarians and to the RIPE editorial board. The OECD project is dedicated to the memories of Stephen Marris and Angus Maddison both of whom helped with this project before their deaths in 2010.

\section{REFERENCES}

Aubrey, H. G. (1967) Atlantic Economic Cooperation: The case of the OECD. Council on Foreign Relations/Praeger: New York/Washington/London.

Barnett, M. N. and M. Finnemore (1999) “The Politics, Power and Pathologies of International Organizations”, International Organization 53(4) 699-732.

Blair, D. (1993) Trade Negotiations in the OECD: structures, institutions and states, Routledge, Chapman \& Hall: London/New York.

Blyth, M. (2009) (ed.) Routledge Handbook of International Political Economy, Routledge: Abingdon.

Camps, M. (1975) First World Relationships: The Role of the OECD. Atlantic Institute for International Affairs/Council on Foreign Relations: New York.

Carroll, P., and Kellow, A. (2011) The OECD: A study in organizational adaptation. Edward Elgar Publishing: Cheltenham.

Clifton, J. and Díaz-Fuentes, D. (2011) "La Nueva Política Económica de la OCDE ante el cambio en la Economía Mundial”, Revista de Economía Mundial, 28, 113-142.

Diebold, W. (1963) “Economic aspects of an Atlantic Community”, International Organization, 17(3), 663-82.

Fratianni, M. and J. Pattison (1976) "The Economics of the OECD”, Carnegie-Rochester Conference Series on Public Policy, 4.

Fratianni, M., and J. Pattison (1982) “The Economics of International Organizations”, Kyklos 35: 244-62.

Gilpin, R. (1971) “The Politics of Transnational Economic Relations” International Organization, 25(5): 398-419.

Gurría, A. (2011) “The OECD at Fifty: Past achievements, present challenges and future directions”, Global Policy 2(3). 
Heilbroner, R. L, (1970) “In Memoriam: Henry G. Aubrey, 1906-1970”, Social

Research: An International Quarterly of the Social Sciences, 37(3).

Henderson, D. (1993) “International Economic Cooperation Revisited: The OECD” Government and Opposition, 28(1) 11-35.

Johnston, D. (2011) “The reform years: Building a stronger, more agile OECD”, The OECD at 50. Better Policies for Better Lives. OECD: Paris.

Kaul, I. Conceição, P., Le Goulven, K. and Mendoza, R. U. (eds.) (2003) Providing Global Public Goods: Managing Globalization. Oxford University Press/UNDP: Oxford/New York.

Kaul, I. and Conceição, P. (eds.) (2006) The New Public Finance, Responding to Global Challenges, Oxford University Press - UNDP, Oxford.

Kellow, A. and Carroll, P. (2011) The OECD: A Study of Organisational Adaptation. Edward Elgar: Cheltenham.

Keohane, R. (1978) "Economics, Inflation and the Role of the State: Political Implications of the McCracken Report” World Politics 31(1): 108-28.

Maddison, A. (2008) “The West and the Rest in the World Economy: 1000-2030. Maddisonian and Malthusian interpretations” World Economics, 9(4), 75-99.

Maddison, A (2007), Contours of the World Economy 1-2030: Essays in MacroEconomic History, Oxford University Press: Oxford.

Maddison, A. (1991) Dynamic Forces in Capitalist Development, Oxford University Press: Oxford.

Mahbubani, K. (2008) “The Myth of Western Aid”, Development and Cooperation, 49 (2).

Mahbubani, K. (2011) “Forum: Can Asia re-legitimize global governance?” Review of International Political Economy, 18(1), 131-139.

Mahon, R. (2006) "The OECD and the work/family reconciliation agenda: competing frames" in (ed) Jane Lewis, Children, Changing Families and Welfare States. Edward Elgar Publishing: Cheltenham. 173-200.

Mahon, R. and McBride, S. (2008) The OECD and Transnational Governance. UBC Press: British Columbia.

Marcussen, M. (2004) “The Organization for Economic Cooperation and Development as ideational artist and arbitrator" in (eds) B. Reinalda and B. Verbeek, Decision-Making within International Organizations, Routledge: London/New York.

Marris, S. (1983) "History of my time at the OECD: Part I and II", unpublished memoirs, speech delivered to OECD Secretariat, 24 and 30 June 1983. 
Martins, K. and Jakobi, A. (2010) Mechanisms of OECD Governance, Oxford University Press: Oxford.

Mold, Andrew (2010) “Maddison’s forecasts revisited: What will the world look like in 2030?, Vox, last accessed on 22 August, 2011, at http://www.voxeu.org/index.php?q=node/5708

OECD (2011a) The OECD at 50: Better Policies for Better Lives, OECD: Paris.

OECD (2011b) Staff Profile Statistics 2010, OECD: Paris.

OECD (2010a) Perspectives on Global Development: Shifting Wealth, OECD: Paris.

OECD (2010b) Financial Statements on the OECD as of 31 December 2010, Paris, OECD.

OECD (2009) Active in Africa, Paris: OECD.

OECD (2006), Resolution of the Council on a New Governance Structure for the Organization, Paris: OECD.

OECD (1977) Towards Full Employment and Price Stability: A Report to the OECD by a group of independent experts, OECD: Paris.

OECD (1960) Convention on the Organization for Economic Co-operation and Development. OECD: Paris.

Pagani, F. (2002) Peer Review: A Tool for Co-operation and Change. An Analysis of the OECD Working Method. OECD: Paris.

Putnam, R., and N. Bayne (1984) Hanging Together: The Seven-Power Summits. Heinemnan/Royal Institute of International Affairs: London.

Sharman, J. C. (2009) "The Bark is the Bite: International Organizations and Blacklisting”, Review of International Political Economy, 16, 573-596.

West, J. (2011) “The OECD and Asia”, Revista de Economía Mundial, 28.

Wolfe, R. (2008) "From reconstructing Europe to constructing globalization: The OECD in historical perspective” in (eds) R. Mahon and S. McBride, The OECD and Transnational Governance, UBC Press, pp. 25-42.

Woodward, R. (2009) The Organisation for Economic Cooperation and Development, Routledge: London/New York.

\footnotetext{
${ }^{1}$ Interviews with OECD officials, Paris, July 2010.
} 


\footnotetext{
${ }^{2}$ Departments include: Development; Economics; Education; Employment, Labour and Social Affairs; Entrepreneurship, SMEs and Local Development; Environment; Financial and Enterprise Affairs; Public Governance and Territorial Development; Science, Technology and Industry; Statistics; Tax Policy and Administration; and Trade and Agriculture.

${ }^{3}$ Special bodies include: the African Partnership Forum; Development Centre; Financial Action Task Force; Global Project Measuring the Progress of Societies; Heiligendamm L’Aquila Process Support Unit; International Energy Agency; International Transport Forum; Nuclear Energy Agency; Partnership for Democratic Governance Advisory Unit and Sahel and West Africa Club.

${ }^{4}$ Committees and sub-committees, of which there are around 250, are constituted by representatives from member countries and experts from the Secretariat. They are organised by theme, such as economic, monetary, trade and education policy, and organise meetings to discuss developments in their specific fields. For a detailed description of the organization of the OECD, see www.oecd.org

${ }^{5}$ Statistics on OECD officials 1961-2011 were kindly provided by the OECD Department of Human Resources.

${ }^{6}$ GDP share is calculated in 1990 international Geary-Khamis dollars, trade in current US dollars.

${ }^{7}$ CFR, a US think tank and publisher, was founded in 1921 with the remit to deliberate on the US's place in the world.
} 
TABLE 1. The OECD in the International

Political Economy 1961-2030

\begin{tabular}{lrrrrr}
\hline & 1961 & 1973 & 1989 & 2010 & $2030^{*}$ \\
\hline OECD members (number) & 22 & 24 & 24 & 34 & 34 \\
\hline $\begin{array}{l}\text { Share of world population } \\
\text { OECD }\end{array}$ & 17.5 & 19.5 & 16.2 & 18.1 & 15.7 \\
$\quad$ Rest & 82.5 & 80.5 & 83.8 & 81.9 & 84.3 \\
\hline Share of world GDP* & & & & & \\
OECD & 53.2 & 58.5 & 56.4 & 50.5 & 43.2 \\
$\quad$ Rest & 46.8 & 41.5 & 43.6 & 49.5 & 56.8 \\
\hline Share of world exports** & & & & & \\
$\quad$ OECD & 55.2 & 70.7 & 70.3 & 59.9 & 41.0 \\
$\quad$ Rest & 44.8 & 29.3 & 29.7 & 40.1 & 59.0 \\
\hline
\end{tabular}

\section{Growth rates (annual average)}

\begin{tabular}{|c|c|c|c|c|}
\hline & $\begin{array}{r}\text { Golden age } \\
1961-1973\end{array}$ & $\begin{array}{l}\text { Cautious } \\
\text { objectives } \\
\text { 1973-1989 }\end{array}$ & $\begin{array}{r}\text { Shifting } \\
1989-2010\end{array}$ & $\begin{array}{l}\text { Wealth } \\
\text { 2010-2030* }\end{array}$ \\
\hline \multicolumn{5}{|c|}{ Population } \\
\hline World & 2.0 & 1.8 & 1.3 & 1.3 \\
\hline OECD & 1.1 & 0.7 & 0.7 & 0.5 \\
\hline Rest & 2.2 & 2.0 & 1.5 & 1.4 \\
\hline \multicolumn{5}{|l|}{ GDP } \\
\hline World & 5.1 & 3.2 & 3.6 & 3.2 \\
\hline OECD & 5.1 & 2.8 & 2.3 & 2.1 \\
\hline Rest & 4.9 & 3.5 & 4.9 & 4.1 \\
\hline \multicolumn{5}{|l|}{ Exports } \\
\hline World & 9.0 & 3.8 & 6.3 & 6.0 \\
\hline OECD & 9.7 & 3.8 & 4.7 & 4.0 \\
\hline Rest & 7.5 & 3.6 & 9.3 & 8.1 \\
\hline
\end{tabular}

"Rest" refers to the non-OECD economies.

* 1990 US international dollars in purchasing power parity terms

** based on current US dollars

* 2030 forecasts are based on OECD (2010a). 